\title{
Correspondence
}

Cerebrovascular Diseases

Cerebrovasc Dis 2008;26:338

DOI: $10.1159 / 000151591$

\section{Estrogen Receptor Alpha Gene Polymorphisms and Stroke}

Sofia Markoula ${ }^{\mathrm{a}}$, Leandros Lazaros ${ }^{\mathrm{b}}$, Nectaria Xita ${ }^{\mathrm{c}}$, Sotirios Giannopoulos ${ }^{\mathrm{a}}$, loannis Georgiou ${ }^{\mathrm{b}}$, Athanassios P. Kyritsis ${ }^{\mathrm{a}}$

Departments of ${ }^{\mathrm{a}}$ Neurology, ${ }^{\mathrm{b}}$ Medical Genetics and 'Endocrinology, University Hospital of loannina, loannina, Greece

We read with great interest the study by Strand et al. [1] concerning the association between estrogen receptor $\alpha$ (ESR1) gene polymorphisms and first-ever intracerebral hemorrhage (ICH). In this population-based case-control study, the authors examined the relationships between ESR1 polymorphisms (c.454-397T $\rightarrow \mathrm{C}$ and c.454-351A $\rightarrow \mathrm{G}$ ), ischemic stroke and $\mathrm{ICH}$. Their results showed that carriers of the c.454-397T/T genotype had a significantly increased risk of $\mathrm{ICH}$, and carriers of the c.454$397 \mathrm{~T} / \mathrm{T}$ or c.454-397T/C genotypes had a significantly higher mean systolic and diastolic blood pressure than carriers of c.454397C/C. However, the association of the c.454-397T/T genotype with $\mathrm{ICH}$, after gender stratification, remained in men but not in women. No relationship was found between ESR1 polymorphisms and ischemic stroke.

Estrogens have vasoprotective properties against atherosclerosis [2], which are mediated through activation of specific estrogen receptors [3]. We have recently investigated the possible association between ESR1 polymorphisms and ischemic stroke in patients with metabolic syndrome [4]. Although no direct association between ESR1 polymorphisms and ischemic stroke was found, several important gender-specific relations were surfaced. The most significant findings were the association of c.454-351A/ A genotype of c.454-351A $\rightarrow$ G polymorphism with the onset of stroke at a younger age in male patients $(p<0.05)$ and the lower $\mathrm{CC}$ genotypic frequency in female patients with ischemic stroke compared to female controls. There were no differences between strokes in a large or a small artery. Our results extend the study by Strand et al. [1] and were in accordance with previously published reports that had demonstrated increased incidence of ischemic heart disease in patients carrying the c.454-397T and c.454351A ESR1 haplotypes [5] and protective properties of the c.454397C allele in the cardiovascular system of postmenopausal women [6] but not of men, where $\mathrm{C}$ allele was associated with atherosclerotic heart disease [7] and c.454-397C/C genotype was re- lated to stroke [8]. In addition, using diplotype analysis we found that female patients less frequently had the CCGG diplotype compared to men and that female patients with TTAA diplotype tended to have a higher stroke incidence compared to females with other diplotypes [4].

Since both the studies by Strand et al. [1] and ours [4] demonstrate a gender-specific impact of ESR1 on the development of stroke (either hemorrhagic or ischemic), these findings should be considered as the consequence of marked differences in the levels of circulating estrogens and gonadal steroidogenesis between males and females. Larger controlled studies are needed for further exploration of gender-specific effects of ESR1 polymorphisms in the development of various stroke types.

\section{References}

1 Strand M, Soderstrom I, Wiklund PG, Hallmans G, Weinehall L, Soderberg S, Olsson T: Estrogen receptor alpha gene polymorphisms and first-ever intracerebral hemorrhage. Cerebrovasc Dis 2007;24:500508.

$\checkmark 2$ Egido JA, Alonso de Leciñana M: Peculiarities of stroke risk in women. Cerebrovasc Dis 2007;24(suppl 1):76-83.

-3 Alonso de Leciñana M, Egido JA: Estrogens as neuroprotectants against ischemic stroke. Cerebrovasc Dis 2006;21(suppl 2):48-53.

4 Lazaros L, Markoula S, Xita N, Giannopoulos S, Gogou P, Lagos G, Kyritsis AP, Georgiou I: Association of estrogen receptor-alpha gene polymorphisms with stroke risk in patients with metabolic syndrome. Acta Neurol Scand 2008;117:186-190.

5 Schuit SC, Oei HH, Witteman JC, Geurts van Kessel CH, van Meurs JB, Nijhuis RL, van Leeuwen JP, de Jong FH, Zillikens MC, Hofman A, Pols HA, Uitterlinden AG: Estrogen receptor gene polymorphisms and risk of myocardial infarction. JAMA 2004;291:2969-2977.

- 6 Herrington DM, Howard TD, Hawkins GA, Reboussin DM, Xu J, Zheng SL, Brosnihan KB, Meyers DA, Bleecker ER: Estrogen-receptor polymorphisms and effects of estrogen replacement on high-density lipoprotein cholesterol in women with coronary disease. N Engl J Med 2002;346:967-974.

7 Shearman AM, Cupples LA, Demissie S, Peter I, Schmid CH, Karas RH, Mendelsohn ME, Housman DE, Levy D: Association between estrogen receptor gene variation and cardiovascular disease. JAMA 2003;290: 2263-2270.

-8 Shearman AM, Cooper JA, Kotwinski PJ, Humphries SE, Mendelsohn ME, Housman DE, Miller GJ: Estrogen receptor gene variation and the risk of stroke. Stroke 2005;36:2281-2282.

Sofia Markoula, MD

Department of Neurology

University of Ioannina School of Medicine, University Campus

GR-45110 Ioannina (Greece)

Tel. +30 265109 7514, Fax +30 2651097011

E-Mailsmarkoula@cc.uoi.gr

\section{KARGER}

Fax +41 613061234 E-Mail karger@karger.ch www.karger.com
(C) 2008 S. Karger AG, Base

1015-9770/08/0263-0338\$24.50/0

Accessible online at:

www.karger.com/ced 